\title{
Morphology and opportunities agricultural valorization: the case northeastern Montenegro
}

\author{
Goran Rajović \\ Street Vojvode Stepe 252, Belgrade, Serbia \\ Phone: 0038161/19-24-850 \\ E-mail address: dkgoran.rajovic@gmail.com
}

\begin{abstract}
Morphology northeastern Montenegro in terms of agricultural valuation is not wells understood. Therefore, the paper discusses the morph metric analysis of the relief: hypsometric structure, the structure of the slope and exposure. Based on morphological characteristics of relief, we selected the observed geographic space, morphological entities with different benefits and limitations for agricultural development.
\end{abstract}

Keywords: Northeastern Montenegro; morphology; agriculture; valorization

\section{INTRODUCTION}

Northeastern Montenegro is a geographical unit, which includes the basin Lima in Montenegro, whose total area is $2.557 \mathrm{~km}^{2}$. Observed geographic space, with around $1.304,1$ $\mathrm{km}^{2}$, or about $51 \%$ of the total surface of are the catchment in the Republic. Northeastern territory of Montenegro includes three municipalities: Berane, Andrijevica and Plav, with an area of $1.486 \mathrm{~km}^{2}$, which is by the census of 2003 , are the 54.658 resident's lived or 36,8 $\mathrm{on} / \mathrm{km}^{2}[1,2]$. The morphology of the observed geographic space in terms of agricultural valuation is not wells understood. The research results been used to examine the author of morph metric analysis relief northeastern Montenegro and separate morphological entities with different benefits and limitations for agricultural development. To what extent the agriculture in this part of northeastern Montenegro serve as the basis for the rapid development of agriculture depends on not only natural factors, but also more of social and other factors.

The geopolitical and economic crisis, considered the geographical space of the Second World War was one of the least developed economic regions of the country. Only since the sixties of the twentieth century, there was a greater degree of valorization of the natural resources of the region, resulting in a faster economic development. Disintegration of the Federal Republic of Yugoslavia or the State Union of Serbia and Montenegro, and the border region receives a peripheral position in Montenegro, which is even more on negative impact economic trends. Given the natural resources, the holder of the economic development in the region, should be farming. 


\section{RESEARCH METHODOLOGY}

This research aims to meet the professional and the public with the morphology of northeastern Montenegro in the geographical context of its exploitation and use. Results of the survey been used to determine the author of the morphological entities that $r$ can cause more rapid agricultural streams and GeoScape considered to provide uniform spatial-functional development. Objective of this study it was possible to realize the combined use of different research methods.

The core of the methodological procedure used in this paper makes geographic (spatial) method. Permeated through the entire text of the analytical method and, thanks to which we are able to recognize, define and evaluate on the basis of morph metric characters of relief northeastern Montenegro morphological entities with different benefits and limitations for agricultural development. Since work has essentially synthetic character, used the results published in the international literature. Among them this time emphasize this [3-7].

\section{RESULTS AND DISCUSSION}

\section{1. Morph metric analysis relief}

Morph metric features of the relief are important for assessing its practical role, especially when it comes to relief, as it developed in this part of northeastern Montenegro. The morph metric analysis procedure is usually taken into account hypsometric structure, the structure of the slope and exposure [8].

Analysis of the morph metric characteristics bees performed using topographic maps scale 1:100.000 [9]. The results been transferred to the overview map. Selection of the basic proportions and scale of the presentation of the results obtained, implied a certain degree of map generalization.

\section{1. 1. Hypsometric structure}

Hypsometric structure reflects the development of vertical relief. In the considered geographic space, it is considerable. Height difference between the highest (Maja Kolata 2528 $\mathrm{m}$ ) and lowest (bottom valley Berane $645 \mathrm{~m}$ ) is $1883 \mathrm{~m}$.

We allocated approximately nine elevation zones with somewhat higher equidistance of $200 \mathrm{~m}$. Altitudinal belts were grouped into three zones hypsometric [10]:

1. Lower hypsometric zone (up to $1100 \mathrm{~m}$ ),

2. Hypsometric Central Zone (from 1100 - $1700 \mathrm{~m}$ ) and

3. High hypsometric zone (above $1700 \mathrm{~m}$ ).

Hypsometric lower zone is the most attractive for agricultural activities. In the northeastern part of Montenegro been affiliated basins and valleys in relief and landscapes to $1100 \mathrm{~m}$ above sea level, which can been roughly taken as the upper limit of rational agricultural production. Storm River alluvial plains, river terraces, lake sediments Berane, Andrijevica and Polimlja basin, have the most favorable conditions for intensive agricultural production.

These are the physical sites where possible use of so-called complete line of machinery for certain agricultural crops. For alluvial rivers are the connected fluvial lands that are the most important aspect of are the production for possible cultivation of most crops. On river terraces as the dominant soil types of different production possibilities, arise vertisols, eutric cambisol, pseudogley and amphigley. According to the natural advantages alluvial river 
terraces and river are suitable for intensive agriculture, particularly crop production. Landscapes that include Plav - Gusinje Basin is characterized altitudes up to $948 \mathrm{~m}$ above sea level and there is a potential use of the so-called. a complete line of machines for certain agricultural crops.

The dominant soil type: fluvisol, locally present, distric camisols, eutric camisols, podsol, planohistol (Plav). Different varieties eutric camisols allow fruit production. This area sub region II belongs to the class of so-called very favorable land for agricultural production. Storm high low areas - mountainous terrain and areas of low medium - mountainous terrain up to $1100 \mathrm{~m}$ above sea level is characterized by greater depth of soil cover (luvisols, vertisols, eutric camisols, distric camisols, and sometimes-represented rendzina). The land is suitable for the production of agricultural crops, primarily orchards, and over $1,000 \mathrm{~m}$ above sea level is mostly woodland, pastures and meadows.

Central Zone includes hypsometric altitudes between $1100-1700 \mathrm{~m}$ above sea level and covers landscapes that are drawn along the valleys of Mountain Rivers in the middle mountainous terrain and lower areas of high mountainous terrain. This spatial entity characterized by thinned pedagogical cover, with the dominant land: rendzina, podsol, calkocambisol, calkomenasol, rankers and scantily and distric camisols, indicating that the majority under grassland and forest vegetation.

These are generally steep mountain slopes, covered with dense forest. Predominantly flat terrain of meadows while the area under plow insignificant (grown mainly potatoes, barley, rye and oats). Abundance of high rainfall contributed to the creation of green areas of meadows and forests, but also a relatively significant volume of arable superficial continuously. A significant part of the arable land is been encountered along small rivers, streams, and on very steep hills. Some people think that a good part of the very steep slopes should cease to be processed and been returned to the original forests and pastures. In one part of this zone is primarily on the edges of the mountains, this is impossible to do, given that it has no other arable land [11]. This zone is particularly suitable for cattle breeding. This zone is particularly suitable for cattle breeding hypsometric zone includes regions above $1700 \mathrm{~m}$ height above represents the most complex and the most prominent entity in which sharpen the contrasts and dynamics of landscapes.

This zone is been represented by the most complex landscapes and ecosystems greatest biodiversity, mountain ranges with a series of sharp ridges, peaks, gaps and divisions. The area of high mountains in is the hydrographic terms, with the exception of Komova, Bjelasica and plateau lakes, characterized by a chronic lack of water [12]. These courts are primarily suitable for forest ecosystems: these spaces sporadically conditionally favorable for meadow - pasture production. The most widespread land is the calkomenasol, litisoli, rendzina and podsol. Are the suitable for tourism development?

\section{1. 2. Structure slope}

Structure slope is the most important agricultural activity for morph metric characteristic. In the narrow space and highly developed vertically and relief of the observed geographic space, structure slope is particularly evident (Map 2). Types and yields of agricultural crops, machinery operation and efficiency of their use, irrigation, soil erosion rate and so to a large extent are determined by the properties of the terrain [13].

It was found that the amount of the annual increase of slope on the northern slopes of the radiation decreases and increases in the south [14]. Thus, the south and southwest of the topographic gradients are very suitable for growing crops that require more heat and light (fruit culture). The increasing slope reduces the amount of moisture in the soil. 


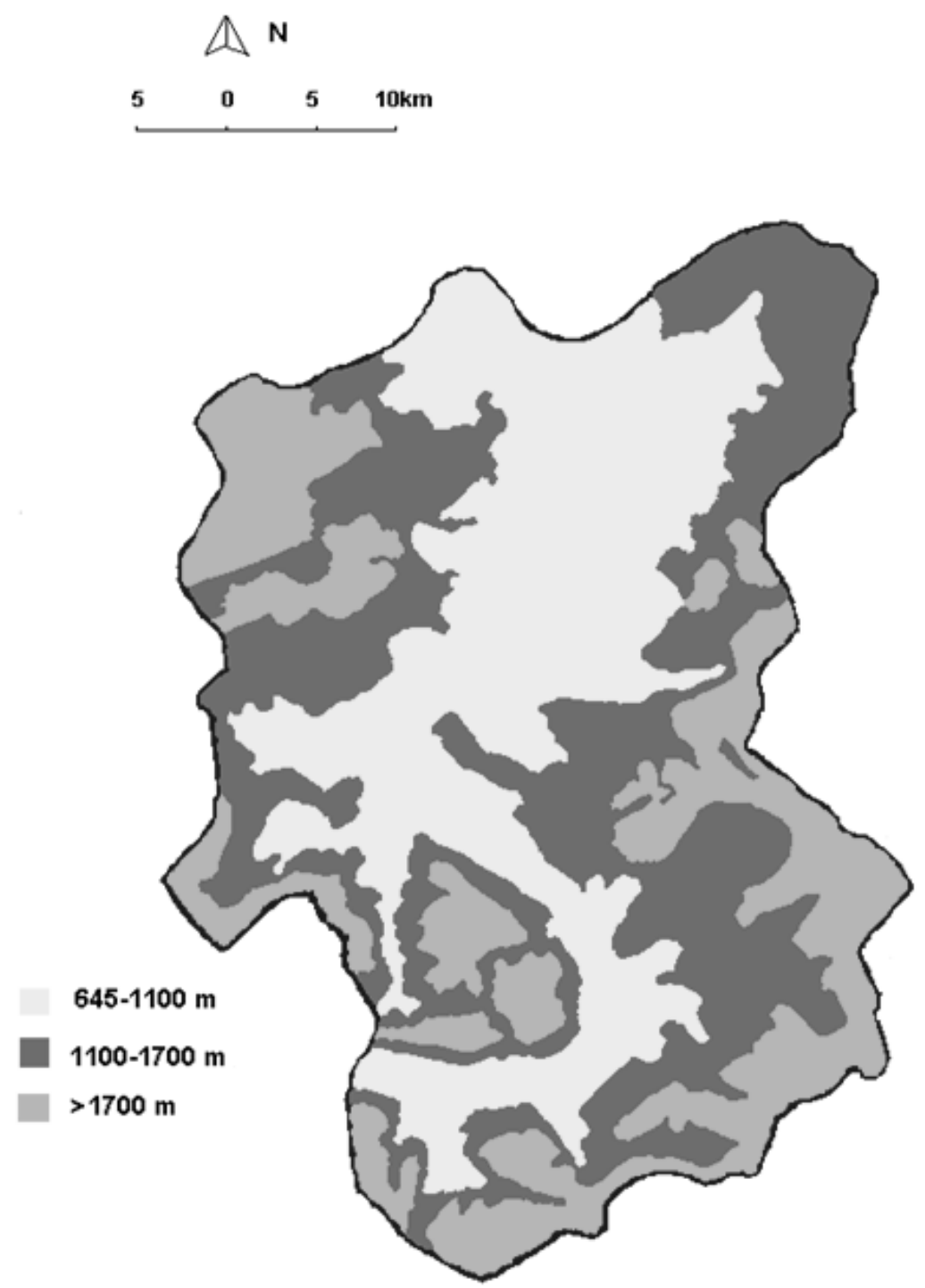

Map 1. Hypsometric structure northeastern Montenegro [11].

In morph metric slope analysis, surface topography can been clenassified:

1. Regardless of fitness for a particular activity, as one of the scales that were established in geomorphologic mapping or

2. Specifically defined by are the requirements of a particular human activity [15]. 


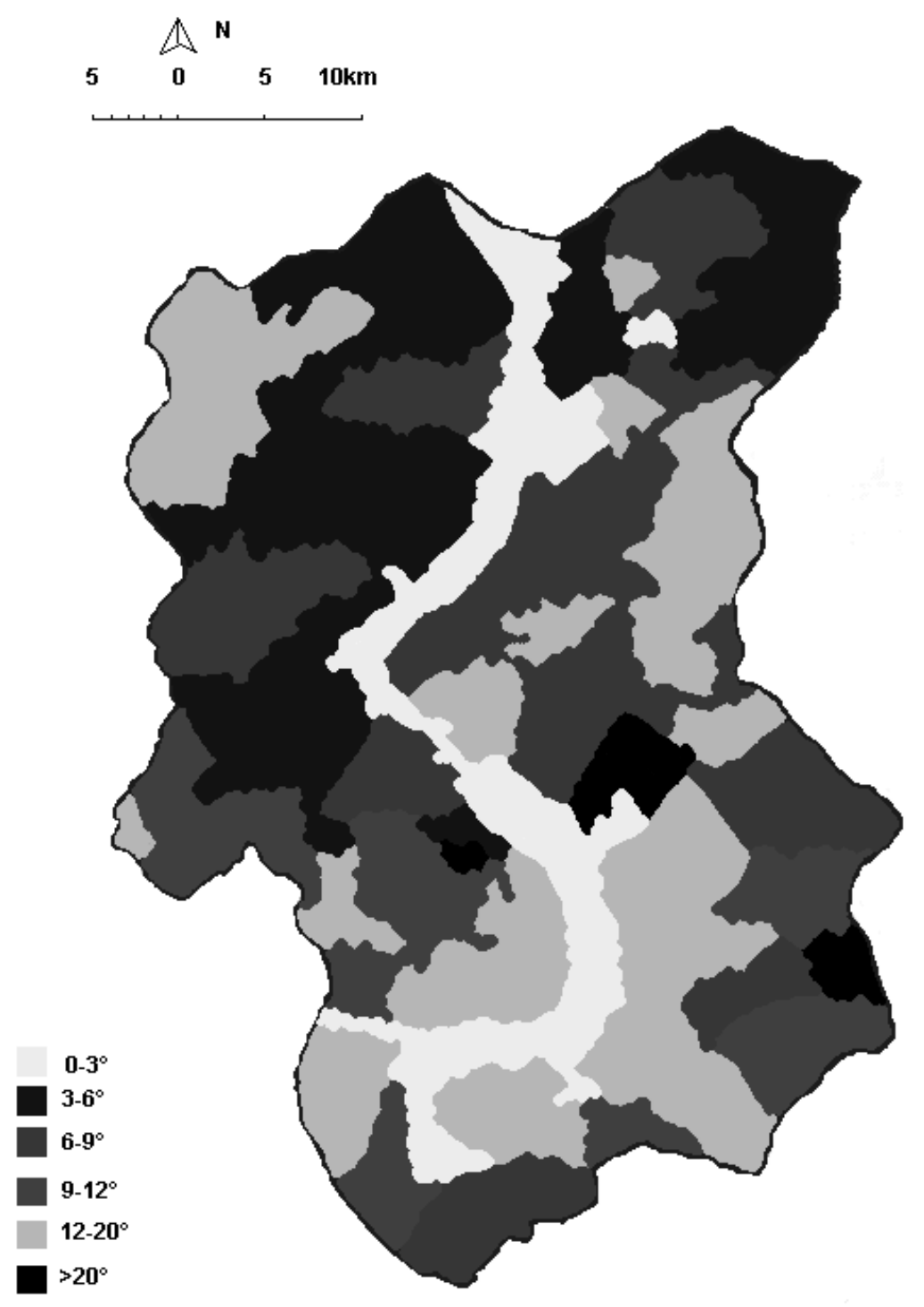

Map 2. The structure of the northeastern slope of Montenegro.

Taking into account the basic design criteria of rural districts [16,17] and the current distribution of agricultural production in the northeastern part of Montenegro [10,18], the usevalue are:

1) First Courts are favorable for crop-vegetable and fruit production with an inclination of $0^{\circ}-12^{\circ}$ and within them there are:

a) Courts intensive crop-vegetable and fruit production with an inclination of about 0 to about 3 . These are the physical sites where it is possible to use the so-called. Is the complete line of machines for certain agricultural crops? Fields with a slope of $3^{\circ}$ to $6^{\circ}$ mainly include river valleys.

b) Courts conditionally favorable for crop-intensive vegetable production and fruit with slopes of $6^{\circ}$ to $12^{\circ}$, requiring contouring, terracing, etc. With is the increase in slope decreases productivity. 
2) Favorable grounds for intensive meadow-pasture and forage crops include slopes of $12^{\circ}$ to $20^{\circ}$, with the use of terracing, it is possible to fruit production.

3) Terrain mostly suitable for forest ecosystems include slopes over $20^{\circ}$. Sporadically are these properties conditionally favorable for meadow-pasture production (slope of $20^{\circ}$ to $35^{\circ}$ ). On this side slopes, if there is no protective cover of grass, there is intense erosion processes.

\section{1. 3. Exposure page}

Exposure affects the topographic surface modification elements, but no character limiting factors. Exposure is the position of the relief forms whose contour direction vertical to the direction of some of the world. According to the meaning can been taking following sequence of values: south, west, east and north. The differences in the amounts of direct radiation exposure between opposite (north south) have more pronounced with increasing slope. At the same slope of the temperature difference between sunny and not sunny slopes ground layer of air can be $6^{\circ}-7^{\circ}$ and at a depth of $1 \mathrm{~cm}$ in the soil for up to $7^{\circ} \mathrm{C}$ [19].

Therefore, the sunny slopes are more heat, the faster they melt snow and more evaporation. For these reasons, the southern exposure spring tillage, planting and fruit ripening earlier than in the north. In addition, western and eastern exposure providing, more favorable conditions for is development of agricultural crops than north.

In the northeastern part of Montenegro is noted that the unexposed surface and good exposure to dominate the geographical areas in which they and other natural conditions are suitable for crop production. For the alluvial plain of major rivers and river terraces, and areas of intensive vegetable production, are typical unexposed area and southern exposure. Unexposed areas occupy the largest expanse of alluvial plain Lima and lower parts of the alluvial plain: Lješnice, Kraštice, Zlorečice, Grnčara, Vrulje, Ljuče and Šekularska River. On underexposed areas represented the entire production of vegetables in greenhouses. Also, depression is characterized by hills and along the borders of good exposure side. The relief is dominated by hills: the southern, eastern and western exposure. Very favorable exposure of peripheral hills: Prosjana, Ćelave towers, Tivrana, Nikolinog grave, Glavice, Paklene, on the right course Lima, Lješnice, Dapsićke, Kaludarske River and Bistrice. Dominant western and southern exposure suitable and for production fruit. Exposure of the mountain rim generally is partly unfavorable - Northern Exposure was dominant on the fringes: Prevjanskog brdo, Sovale, Sjekirice, Peštera, Bivoljka, Konjskog brda, Konjskog krša and Mokre mountains southern and southwestern exposures were dominant on the edge: Lopara, Bukovnika, Divjaka, Crnog top, Grebena, Pelinovica i Piševa.

Generally, adverse northeast, north and northwest exposure at high mountain ranges dominate the south-eastern and southern edge of the mountain, or on the slopes: Mramorja, Turjaka, Maja Špatita, Karaule, Štavne, Bora, Kofiljače, Štita, Skrivene i Cmiljevice. Something better exposure with the western and eastern rim and slopes: Carina, Suvog vrha, Crne glava, Dolova, Troglave i Maja Made [20].

On sunny exposures are: Turjak, Štavna, Skrivena, Cmiljevica, Starac, Maja e Špatit, Kofiljača, Bor, Karaula and Mramorje; while on sunny exposures that are not: Dolovi, Crna glava, Suvovrh, Prijedolska glava and Maja Made.

\section{2. Morpholpgical entites}

The relief of the region is been considered an important factor in economic development. According to economic significance, are two major morphological groups: composite Lim 
valley and mountainous hinterland? Lim is the most important geomorphologic whole region. Throughout its length built roads linking major regional northeastern parts of Montenegro, enabling a more even economic development. Basins Berane, Andrijevica, Polimlje and PlavGusinje have the best soil conditions for intensive agricultural production. Pronounced horizontal and vertical articulation of relief in the region considered is a limiting factor for intensive agricultural production, building infrastructure systems and spatial expansion of settlements. Relief dissection makes the construction of electricity networks, telephone lines and radio and television transmission [21].

According to the basic forms of relief in the highlands of the northeastern part of Montenegro, in terms of agriculture, we can extract [10]:

1. Valley Berane, Andrijevica, Polimlje, Plav-Gusinje and hilly and mountainous regions up to $1100 \mathrm{~m}$ above sea level,

2. Mountainous region of $1100 \mathrm{~m}$ above sea level to $1700 \mathrm{~m}$ above sea that make mountains Kruščica (1192 m), Male (1212 m), Sovale (1320 m), Balj (1379m), Turjak (1461 m), Šesteverac (1472 m), Trešnjevik (1573 m), Međušten (1660 m), Skrivena $(1688 \mathrm{~m})$ and others,

3. Mountainous regions above $1700 \mathrm{~m}$ above sea level, which include wet mountain (1933 m), Cmiljevica (1963 m), Visitor (2015 m), Bjelasica (2122 m), Komovi (2211 $\mathrm{m})$ and Prokletije $(2372 \mathrm{~m}$ ). (Basic forms of altitude are given to facilitate determination of morph metric relief benefits, primarily the impact of morph metric traits in agriculture).

Valley Berane lying between is mountains Bjelasica and Cmiljevica at an altitude of about $645 \mathrm{~m}$. In the narrow sense, the tectonic-erosive extension incorporated into the police, and other senior Krčevo surfaces. Surrounded by many rocks that fall to are bottom of a steep valley, at an altitude up to $800 \mathrm{~m}$. $\mathrm{t}$ stretches in the northeast - southwest nine miles in length and width from 2.5 to $5.0 \mathrm{~km}$ [22]. In mid-flowing rivers Lim and shared Berane Basin in two spatial areas. The alluvial plain is at the absolute height of 645-703 m accrete planes: Brnjice, Dapsićke, Kaludarske and Bistrica River. To the north, about Marsenića River narrows to 1 $\mathrm{km}$. Alluvial plain muzzles, Dapsićke River, Bistrica, Kaludarska (which only belong to the lower part of its valley Berane) are much smaller space. Width of are alluvial plain at the mouth of the river Lim in the range of tens to hundreds of meters. With this aspect of agricultural production is the most important form of relief in Berane valley. Alluvial plain of the river is been characterized by favorable structure of the slope (the slope of the $0^{\circ}$ to $3^{\circ}$ ), unexposed surface and fluvial hydro orphic high production potential. Therefore, for these forms of relief concerning agricultural production, and in general, is greatest concentration of human activities. On the right side of the basin is represented Neocene undulating landscape in which alternating valleys and lower elevations (Jasikovac, Dubica, Dapsićko hill). The relief on the left side features three fluvial-glacial terraces. A higher altitude of 718 meters and width of 300-1000 m (the move from the farm to the Hague, Škrnjevice), and the lowest terrace is situated at an altitude of $673 \mathrm{~m}$. Upstream of Berane all lower, while almost disappears. This phenomenon can be explained by the fact that the water is applied and "choking" in a narrow opening in a limestone gorge and the river had to meanders alluvium by creating a flat terrace [22]. However, as the inter-valley hair asymmetric, with the steeper northern slopes, terraces right hand: Brnjice, Dapsićke, the Bistrica River and Kaludarska occupy very small area. In the value from the point of view of production agriculture, river terraces behind the flood plains of rivers. This form is characterized by slope of the terrain from $0^{\circ}$ to $6^{\circ}$, and unexposed southern exposure and is beyond the reach of the flood waters and groundwater. For river valley soil 
types are associated heavier texture and unfavorable water-air properties (vertisols, eutric camisols, pseudogley), But river terraces are suitable for growing most crops.

In the Northeast region extends Police in the shape of flattened surface. Shelf covers an area of $33 \mathrm{~km}^{2}$ and extends towards the northeast - southwest 8 miles, and in the south - north 5 miles. Pumping her bottom ranges from 780-920 rounded we characterized the hills and gentle slopes. At the entrance to the gorge Tivransku, Lim splits into two branches. Today, between the backwaters raises limestone human head elevation, about $100 \mathrm{~m}$ above the river bed. In both Diluvia sleeve was filled with fluvial-glacial drift, but after this phase, most common is the left channel, so that the bed of the right islands remained dry. Neocene fluvial terraces of the corresponding small limestone plateaus on both sides, whose side are falling vertically into the trough $120 \mathrm{~m}$ [22].

Low mountainous terrain includes part of the North Tivrana, Prosjane the northeast, part Krčevsko - Peštarske surface in the east and Citadels Dolac and the West. Mild forms of relief, and the slope of the $\left(6^{\circ}\right.$ to $\left.9^{\circ}\right)$, and greater depth of soil cover (vertisols and eutric camisols), make this whole relief suitable for agricultural production. The current distribution of agricultural production in this part of the relief, in addition to arable, is been related to the area under orchards. The area between the river Brzava (Prevjansko hill about $1100 \mathrm{~m}$ ) and Lima, a mild form of relief, and the slope of the $\left(3^{\circ}-6^{\circ}\right)$, are suitable for agricultural production. Given that are dominant land - vertisols and eutric camisols. Also, the left and right sides Lješnica (consisting Petnjička and Vrbička rivers), Korajskog up the hill to the east, the south Đuča, Tiganjskog top of the southwest and west of the Dubai landscape, characterized by the slope of $6^{\circ}$ to $9^{\circ}$ and mild forms of relief, suitable for agricultural production.

In the area between the Sutjeska canyon in the south to enter Lima in Marsenićko stricture length of $9.5 \mathrm{~km}$, developed Andrijevica valley at an altitude of $800 \mathrm{~m}$. Represents a tectonic a modified extension of erosive fluvial denudation-Lima and its tributaries: Zlorečice and Kraštice. Causing enormous material tributaries, Lima pushed the bed to the east, so that only the left side, extending along the valley alluvial plains and glacial-fluvial terraces [19]. Alluvial space is most pronounced in the immediate valley of Lima (the absolute altitude of 703-740 $\mathrm{m})$, which accrete planes: Zlorecice and Kraštice. Of Sutjeska canyon, has extensions at the mouth Zlorecica (alluvial plain of about $1 \mathrm{~km}$ ) and Kraščice (alluvial plain 1.8 miles), and the downstream expansion in valleys: Zabrđa, Slatine and Trešnjeva. This is the most important form of relief Andrijevičke Valley and the structure is characterized by a favorable angle of $0^{\circ}$ to $3^{\circ}$, and unexposed exposure is extremely favorable for agricultural production. A special section covers the area around the Kralja River Valley crust, spreading under moderately steep terrain $\left(3^{\circ}\right.$ to $\left.6^{\circ}\right)$, dissected waterways, often with gentle slopes and fractures. A second area Konjuhe, the neighborhoods around Zlorečica, in which the basin: Kutski rivers and Perućica. On both sides Zlorecica, reveals stairs cultivated terraces with steep sections. The area around Kralja and Konjuhe, characterized by gently sloping terrain in addition to $\left(3^{\circ}\right.$ to $\left.6^{\circ}\right)$ and good soil production potential (eutric and distric camisols eugley), Most suitable for growing crops. Kutski river valley of the river can be seen as favorable for the production of certain crops (barley, oats, corn), and fruit from the mouth: Zlorecica to Cecuna. Further to the source, geomorphologic characteristics that make a home on the land are not favorable for agricultural production.

The area above the valley Andrijevica to $1100 \mathrm{~m}$ above sea level covers the base just in the east, to the west Trešnjevik. Relief forms and the slope of the $\left(3^{\circ}\right.$ to $\left.6^{\circ}\right)$, are highly favorable for the production of certain fruit and vegetable crops. The river valley Perućica have excellent soil (luvisols, eutric camisols), Suitable for agricultural production. The third section includes a river valley with a small river Šekularska expansion in Madžgalj. The complex is 
characterized by a slope of up $6^{\circ}$ to $9^{\circ}$ and steeper relief forms. Šekular his position leaning towards are valley of Lima, which makes it suitable for farming.

Sutjeska canyon to the south, a distance of $2 \mathrm{~km}$ and a depth of $840 \mathrm{~m}$, and makes the connection between the beginning Polimlje and Andrijevica basin. Polimlje valley stretches to the southeast Glavice a length of $12 \mathrm{~km}$, while the width is nowhere greater than $1.5 \mathrm{~km}$. According to data Kasalica [19], the geomorphic structure is dominated Brezojevička alluvial fans, alluvial plain Lima (764-875 m), the gentle valley and ordered stepped fluvial-glacial terraces. Therefore dominates the landforms that been almost localized in a number of settlements, almost without exception, characterized by favorable topographic position (Velika, Pepići, Upper Ržanica, Mašnica, Murino, Kruševo and Ulotina). Upstream of Ulotina, Plav faces in the direction of the greater expansion (terraces) that are favorable for agricultural activities (luvisols, eutric camisols).

Storm to $1100 \mathrm{~m}$ above sea level on the left side of Lima, from the extension Luga to the Pepića, characterized by a slope of $3^{\circ}$ to $6^{\circ}$, and are very suitable for agricultural production (excluding head Jerinje landscapes with slopes up to $6^{\circ}$ to $9^{\circ}$, a lot of bad geomorphologic features, with moderately suitable land for agricultural production). Storm on the right foot Lima include Rasojevićke head, Javorišta, Grahovac, Koradžinog hill, Prijedola, it is from the mouth of the river to the Upper Piševske River to Ržanica in moderately favorable for agricultural production.

Plav - Gusinjska valley, situated between Visitorsko - Prokletajskog frame (the absolute altitude of 764-948 m, the length between the furthest points to $33 \mathrm{~km}$ and the maximum width of about $4 \mathrm{~km}$ ), in many geomorphologic characteristics of the character of a basin - deep in relation to the above background from 1346-1622 $\mathrm{m}$. In fact, part of the valley, which been developed between Vjeternik and Glavica (farthest glacial moraines Plav), a distance of 21 miles or so from Gusinje said entire series moraine $15 \mathrm{~km}$, has the characteristics of a terminal glacial basin in which the lowest part $(907 \mathrm{~m})$ is Plavsko Lake. Moraines in rows extending from are lake to the village - Novšića. Powerful moraines are within the area of a sketch, and the area known as Zakrš. According to are Lima valley area expansion in the valley of the Đuricke and Komarače River. These take the form of glacial valleys wave. By are middle of the narrow alluvial plain $(780-890 \mathrm{~m})$, above which rise in steps fluvial - glacial terraces and alluvial fans. Furthermore, the older moraines, gravelly alluvial fans continue until Brezojevičkog field expansion at the mouth of the: Veličke and Murinske River. By are bottom of the basin, meandering river and its tributaries Ljuča. From Gusinja, basin extends along the glacial valley: Grnčara, Bistrice, Dolje and Vrulje River [23]. This whole area is very favorable for agricultural production (slope of $0^{\circ}$ to $3^{\circ}$, Class II very suitable land for farming, good geomorphic features).

Storm over Plav-Gusinje valley up to $1100 \mathrm{~m}$ above sea level including the left Lima, Ljuče and Grnčara foot Visitor and Grebena; footer Trojans, Karaule, Bora and Kofiljače left side Grnčara, Bistričice, Bistrice, Dolje, Vrulje, Đuričke River and Komarače and Veličke River, pedestal Pršovog karst to Đelove towers. We can in this space as a whole, distinguish the following regions moderately suited for agricultural production: Skavkača valleys and streams Bilećkog; Jaseničke River; Valley where part of the Treskavička and Tamnjanska rivers flowing into the area between mosquitoes and Novšića and Veličke River. Marginally suitable facilities, including part of are left and right sides Vrulje. All other areas, including are fields unsuitable for agricultural production.

The mountain landscape of $1100-1700 \mathrm{~m}$ above sea level, locally cut by deep river valleys cut into. This spatial unit characterized mainly with severe forms of the relief angle $12^{\circ}$ $-20^{\circ}$. This region has rolled land cover, with the dominant land: rendzina, podsols, calc- 
camisoles, rankers, and in places and districts camisoles suggesting that the predominantly grassland and forest vegetation (forest pine, spruce, beech, oak, fir). This relief unit is suitable for cattle breeding. Given that, for each food crop biologically determined minimum, the area near the river valleys (for example, Kutski River or at the foot of the Vlahova and Javorišta) it is possible to grow certain crops (wheat, barley, oats, peas, beans, and rye), orchards and grasslands (dominated eutric camisols and rendzina). This spatial whole of $1100-1700 \mathrm{~m}$ above sea level is attractive for the development of sports, mountain, hunting and eco-tourism [24-26].

In the high mountain zone above $1700 \mathrm{~m}$ above sea level been exacerbated by the relief and soil conditions. The slope of the spatial structure of the completely dominant slopes is over $18^{\circ}$, and slopes over $20^{\circ}$. Most land is represented as calkomenasol, litisoli, rendzina and podsol, so this area under forest vegetation and mountain pastures with blueberry and juniper (except where the parent material litisols). These spatial units above $1700 \mathrm{~m}$ above sea level, it is suitable for tourism development, of which one has to start to solve almost all issues of spatial organization of mountain tourism construction.

\section{CONCLUSIONS}

Morphology of geo considered a solid basis for agricultural valuation, given that the diverse and evenly distributed. Harmonious economic development in the future will depend on many factors, which at the end of the twentieth century proved too been limited. State agriculture at the beginning of the twenty-first century is fraught with numerous problems. Specifically, 1964 the agricultural land in the region included: 70.478 ha, 1994-68.050, 200067.740 ha. Thus, agricultural areas been reduced to 2738 ha, i.e. by $3.8 \%$, or an average of 105 ha each year. 's Say, that the basic characteristics of manufacturing units in the region, fragmentation of holdings. The average size of private farms is 6.19 ha. However, if one takes into account the farmland, then the average size is been reduced to 2.91 ha.

The reasons are found in its traditional agrarian structure, unregulated and inheritance law, insufficiently thought out agricultural policy, which makes the implementation more efficient and productive agricultural production and generates additional manufacturing costs, while preventing influx and cost-effective major investments, especially in completing the necessary machinery [27].

Mentioned necessary add and that only by erosion, the total area of forest land and agricultural (129 $811 \mathrm{ha}$ ), according to the Municipal Secretariat of Economy municipality Berane, Andrijevica and Plav, was attacked about eighty thousand acres of land.

Agricultural land does not possess in the region to such an extent as is often thought and emphasize. "Agricultural land should be good to keep and extremely rational use. Unfortunately, every year hundreds and thousands of acres of farmland irretrievably lose. In places recently acres in the most favorable areas for agriculture usually near urban areas, as well as major roads, appeared to cottages, industrial halls, warehouses, warehouses, parking lots, and even dump " [28].

Therefore, preserving agricultural land and increase its fertility in the region in the coming months, it is necessary to pay special attention. Rational use should be a major focus of economic policy under study GeoScape. Stable and productive farming, involves the use of scientifically based methods in that operation, and the process for its protection. Today of course we have the knowledge and resources they are able to do so fertile agricultural land (example Denmark), than it is created by nature [28]. 


\section{References}

[1] Rajović G., Bulatović J., International Letters of Social and Humanistic Sciences 4 (2013) 11-21.

[2] Rajović G.,Bulatović,J., International Letters of Social and Humanistic Sciences 3 (2013) $10-20$.

[3] Lightfoot R. D., Geographical Review 84 (2) (1994) 112-123.

[4] Antrop M. (2002). Rural-urban conflicts and opportunities, In Jongman R(end) New dimensions of the European landscape, Wageningen University Research Front is Series, Netherlands, 2002.

[5] Bills L. N., Food, agriculture, and the emergent service economy: Implications for the Northeast region, The Northeast Regional Center for Rural Development, Pennsylvania State University, 2004.

[6] Thapa B. R.,, Murayama Y., Land evaluation for peril-urban agriculture using analytical hierarchical process and geographic information system techniques: A case study of Hanno, Land Use Policy, Volume 2, United Kingdom,2 008.

[7] Thapa B. R., Borne F., MurayamaY., GeoJournal Library 100 (4) (2011) 193-214.

[8] Dinić J., Theoretical and methodological basis of regionalization and evaluation of natural conditions and natural resources, Center for Multidisciplinary Studies, Belgrade, 1978.

[9] Topographic map 1:100,000, Ivangrad, Peć and Skadar, Military Geographical Institute, Belgrade, 1986.

[10] Rajović G., Geographical basis for the development of the economy Upper Polimlje, Printing Vedes, Belgrade, 2005.

[11] Rajović G., Annals of the University of Oradea-geography series 1 (2011) 113.

[12] Đerković Š Z., Agricultural development strategy in view of regional economic development, Institute of Agricultural Economics, Belgrade, 1992.

[13] Nikolić S., Nature and Tourism of Montenegro. Institute for the Protection of Nature, Podgorica, 2000.

[14] Narcisov V. P., Naučnije osnovi sistem zemledelija, Kolos, Moscow, 1976.

[15] Seholz E., Einfuhrung in die Kartographie und Luftbildingerpretation, Studien juscherci-geographie, Gotha, 1973.

[16] Simonović Đ., Rural apartment, P. C., 53, Faculty of Architecture, Belgrade, 1980.

[17] Kojić B., Development of houses and housing culture in Serbian villages, "Education", Belgrade, 1980.

[18] Volf M., Dimitrovskij J., Geografija mirovogo hazajstva, Misl, Moscow, 1981.

[19] Kasalica S., Northern Montenegro, University word, Nikšić,1988.

[20] Rajović G., Bulatović J., International Letters of Social and Humanistic Sciences 2 (2013) 1-17. 
[21] Pavlović M., Šabić D., Vujadinović S., Serbian Geographical Society 89(2) (2009) $3-26$.

[22] Lutovac V. M., Valley Ivangrad (Berane), Serbian Academy of Sciences and Arts, Belgrade, 1957.

[23] Bakić R., Popović S., Radojičić B., Burić M., Kasalica S., Ivanović Z., Vukotić M., Geography of Montenegro - factors of population redistribution, University for Nikšić, 1991.

[24] Rajović G., Bulatović J., Journal of Energy and Natural Resources 2(2) (2013) 7-20,

[25] Rajović G., Bulatović J., International Letters of Social and Humanistic Sciences 6 (2013) 24-35.

[26] Rajović G., Bulatović J., International Letters of Social and Humanistic Sciences 6 (2013) 49-61.

[27] Rajović G., Journal of Economics 55(6) (2009) 33-44.

[28] Rakićević T., Proceedings of the Geographical Faculty of Natural Sciences and Mathematics Faculty 36 (1989) 17-18. 